\title{
Building City Identities: A Consumer Perspective
}

Delphine Godefroit-Winkel

Toulouse Business School, Casablanca

Marie Schill

Université de Reims Champagne Ardenne

Cristina Longo

Université de Lille

Martin Chour

EDHEC Business School, Lille

Follow this and additional works at: https://digitalcommons.uri.edu/mgdr

Part of the Arts and Humanities Commons, Environmental Studies Commons, Marketing Commons, Nonprofit Administration and Management Commons, Real Estate Commons, Social Psychology Commons, Sociology Commons, Tourism and Travel Commons, and the Urban Studies and Planning Commons

\section{Recommended Citation}

Godefroit-Winkel, Delphine; Schill, Marie; Longo, Cristina; and Chour, Martin (2020) "Building City Identities: A Consumer Perspective," Markets, Globalization \& Development Review. Vol. 5: No. 2, Article 4. DOI: 10.23860/MGDR-2020-05-02-04 Available at: https://digitalcommons.uri.edu/mgdr/vol5/iss2/4

This Article is brought to you for free and open access by DigitalCommons@URI. It has been accepted for inclusion in Markets, Globalization \& Development Review by an authorized editor of DigitalCommons@URI. For more information, please contact digitalcommons-group@uri.edu. 


\section{Building City Identities: A Consumer Perspective}

\section{Cover Page Footnote}

The authors want to thank all the informants who kindly participated in this investigation, and shared their experiences of living in Casablanca. 


\section{Markets, Globalization \& Development Review}
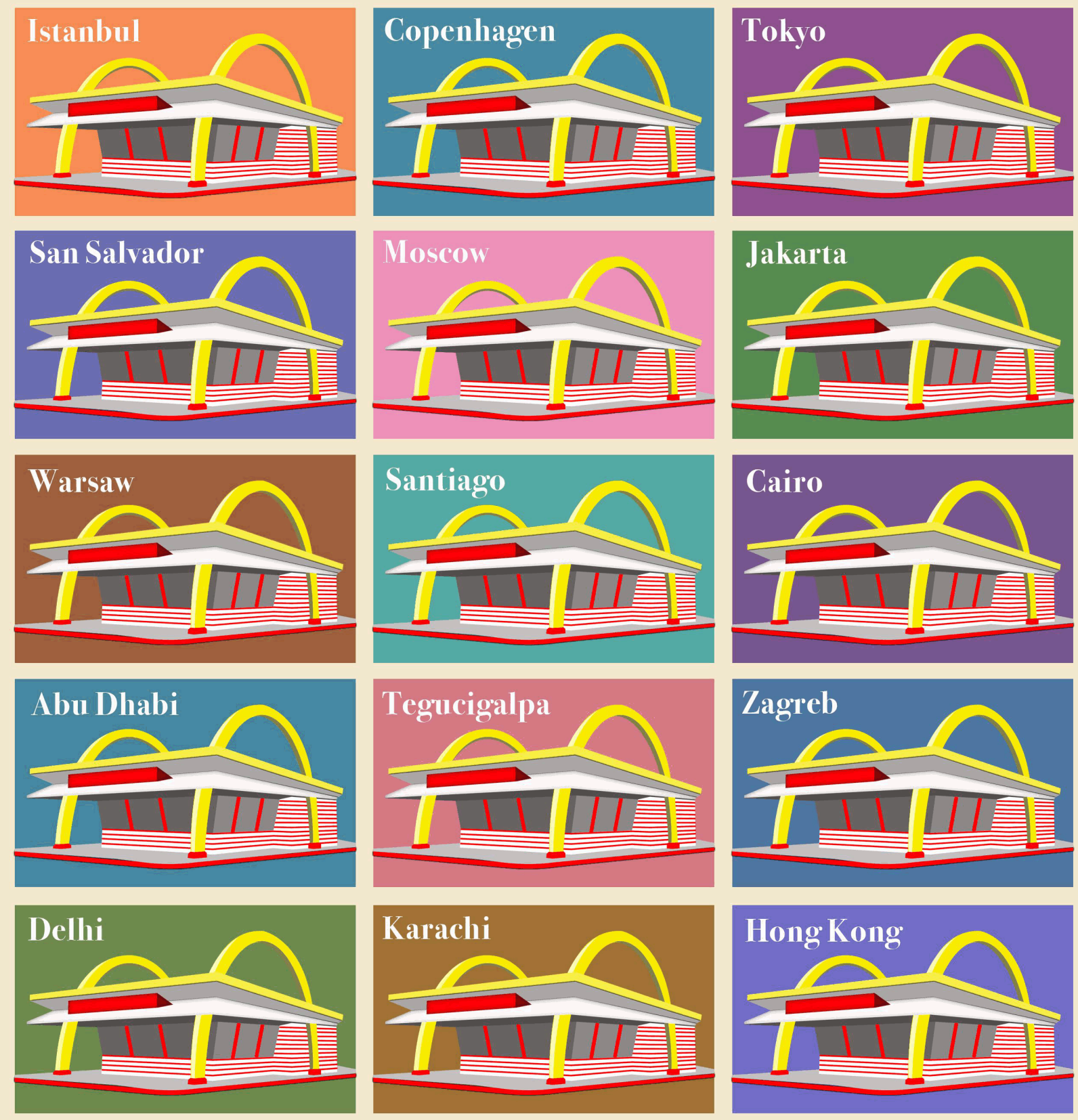

This article is available in Markets, Globalization \& Development Review: https://digitalcommons.uri.edu/mgdr/vol5/ 


\section{Building City Identities: A Consumer Perspective}

\section{Introduction}

Within a globalized world where the local and the global are interdependent (FIrat 2016), marketers around the world have increasingly devoted time and efforts to develop marketing strategies aimed at promoting city identities and increasing city attachment. Among the many cities that are trying to shape their identities with branding campaigns are London ("Totally-London"), Madrid ("Madrid"), Amsterdam ("I amsterdam"), and New York ("Greenyc").

Global connectivity and complexity (Sarkar 2019) call for overcoming simplistic assumptions that are often mobilized in overused research techniques (Dholakia and Atik 2019). In city branding specifically, we observe limits to marketers' strategies about city identity and city attachment (Skinner 2008). Many elements outside the control of city managers conflict with city branding strategies. Cities convey a myriad of elements that consumer residents use to build their city experiences (Stocchi, Hart and Haji 2016) and develop their city perceptions, like 'neighbor days' that foster specific senses of city life. Although it is important for marketers to understand how consumer residents construct their city identities, many have limited their scope to city branding, paying little attention to studying cities from the consumer perspective. This research aims to fill this gap.

As residents shop, visit, work, and, more generally, consume in various urban spaces of their cities, they develop attachments (Insch and Florek 2010; Taylor 1996). Quantitative studies (Casakin, Hernández and Ruiz 2015; Droseltis and Vignoles 2010) provide valuable insights on how residents identify with their cities. These, however, have not explored consumer residents' emotional bonds with their cities. Consumer residents may live in residential areas, work in business districts, and shop in outlying malls. These places and spaces have distinct characteristics, and elicit various emotions. Yet, we know little about how consumer residents build city identities through their experiences of these urban spaces. Thus, in this study, we pose this question: How do consumers integrate heterogeneous elements, like spaces and place-characteristics, emotions, consumption experiences, to build city identities?

Given the lack of knowledge about the interplay among city attachment, consumption, and urban spaces in city identity building, it 
seems imperative to develop a more complete understanding of city identities from a consumer perspective.

In the first section of the paper, we review prior literature on city identity and city attachment. In the second section, we describe our methodological approach and introduce Casablanca, Morocco, as the site of our research. Our results contribute to consumer literature on city identity (Skinner 2008) and city attachment (Hummon 1992; Lewicka 2011b); they also lead to managerial recommendations for city branding. Finally, we acknowledge limitations of our study and provide directions for further research.

\section{Literature Review}

Scholars have long used the terms 'place attachment' and 'place identity' interchangeably (Giuliani and Feldman 1993; Pretty, Chipuer and Bramston 2003). These terms, however, are distinct (Casakin, Hernández and Ruiz 2015; Kavaratzis and Hatch 2013); and we explore these distinctions next.

\section{City Identity}

Place identity is the internalization of place into the larger concept of self. It is a potpourri "of memories, conceptions, interpretations, ideas, and related feelings about specific physical settings, as well as types of settings" (Proshansky, Fabian and Kaminoff 1983, p. 60). Place identity relates to how a place is understood and perceived (Casakin, Hernández and Ruiz 2015). Therefore, place identity remains outside the control of marketers (Skinner 2008).

Place identity is developed through the participation of various stakeholders. Because individual stakeholders carry various ideas, beliefs, preferences, values, and objectives (Skinner 2008), they share distinct personal relationships with the immaterial and material elements provided by places (Mayes 2008). For example, built environments, infrastructures, and local communities are all elements that residents may use to construct personal city identities. They contribute to the ascribing of multiple identities to places (Skinner 2008). These identities vary according to consumer residents' mindsets and experiences (Wester-Heber 2004). Because people's interests are versatile and change over time, place identity building is a dynamic, ongoing process (Kalandides 2011). Indeed, how do consumers build city identities?

Scholars have uncovered the rich variety of meanings carried by distinct places within the same cities; this heterogeneity could cause a sense of confusion about city identity (Skinner 2008). Nevertheless, we 
know little about how urban spaces and city identities interact, that is, about the interplay between spatial types and city identities.

Castilhos and Dolbec (2018) identify four types of city spaces that have different dynamics and meanings to residents: (1) public, (2) market, (3) emancipating, and (4) segregating. Although the authors do not focus specifically on city identity, they show that distinct spaces in cities provide consumer residents with opportunities to engage in specific negotiations. The four types of spaces relate to distinct dynamics; for example, they may either contest or create consensus around social norms.

Specifically, the logic of negotiation characterizes public spaces and market spaces. In public spaces, consumers negotiate via consumption styles, norms, and styles of etiquette related to their social differences. In market spaces, the discursive and material authorities of market stakeholders affect negotiations. Shops, shopping centers, and entertainment venues provide specific material affordances through their built environments that encourage consumer residents to perform consumption roles.

Unlike public spaces, market spaces host consumers who can afford to patronize such places and who behave according to scripted norms.

Dissimilar to public and market spaces, the logic of consensus characterizes emancipating and segregating spaces. Emancipating spaces facilitate resistance and subversion; they allow safe expression, like Burning Man festival (Kozinets 2002), and help challenge the hegemony of social norms. Segregating spaces foster social reproduction through their sense of privacy, identity, and control; they include places such as residential resorts, gated communities and private clubs.

Castilhos and Dolbec's (2018) typology offers an interesting framework to understand power dynamics within urban spaces. By building on this typology, we can help clarify how negotiations in such spaces contribute to specific city identities.

In summary, little attention has been paid to how consumer residents develop and contribute to the building of city identities in relation to their consumption experiences. Hence, we aim to study distinct city identities. In the next section, we examine prior literature on city attachment and related emotions.

\section{City Attachment and Emotions}

In social sciences generally, 'identity' and 'attachment' are clearly demarcated concepts; and it is important to make this demarcation in relation to the social side of cities. Literature on city attachment derives essentially from works on place attachment in environmental psychology 
(see Hummon 1992 and Lewicka 2011a for an extensive review). Place attachment is a 'cognitive-emotional bond that forms between individuals and their important settings' (Scannell and Gifford 2017, p. 256). Although attachment relates to the interplay between affect and emotions, knowledge and beliefs, and behaviors and actions (Kavaratzis and Hatch 2013), most research focuses on the emotion of place (Lewicka 2011a). In this vein, city attachment relates to residents' emotional ties to their cities of residence (Giuliani 2003). The establishment of affective bonds with cities has strong implications for people's lives. For instance, when people feel comfortable and safe in a city, they tend to reside longer there (Hernández et al. 2007). In contrast, those who do not develop affective ties with their cities are more inclined to leave (Twigger-Ross and Uzzel 1996).

Hummon (1992) illustrates five ways in which consumers relate to their places of residence. The terms 'everyday rootedness' and 'ideological rootedness' describe strong attachments to such places. Ideological rootedness refers to the conscious decision to live in a city, whereas everyday rootedness describes situations in which consumer residents take their cities for granted and have scarce opportunities to compare their cities with others. Three negative attitudes toward place alienation, relativity, and placelessness - are instead associated with weak attachments. Place alienation corresponds to dislike of a place, place relativity refers to an ambivalent and conditionally accepting attitude toward a place, and placelessness alludes to indifference to the need to create emotional bonds with a place.

The most common emotions associated with place attachment are positive, such as happiness, love (Debenedetti, Oppewal and Arsel 2014), and nostalgia (Fried 1963). Emotions may be linked to interpersonal relations (Insch and Florek 2010). For example, Fried (1963) notes that residents may express forms of nostalgia toward their former neighborhoods even if their new locations present higher standards of living; they complain about loss of familiarity or social interaction. In unsafe neighborhoods, interpersonal bonds also tend to be extremely strong. Therefore, residents tend to respond to local deterioration and crime with higher rates of neighborhood attachment. Notably, attachment is not weaker in poorer or unsafe neighborhoods than in other neighborhoods (Taylor 1996). Though these insights are helpful to understand how consumer residents emotionally engage with their city, the relationship between negative emotions and attachment to cities remains understudied. 
Consumer research recognizes that place attachment has strong links with consumption. Stocchi, Hart and Haji (2016) show how residents display higher levels of willingness to stay in city centers, or revisit them, when they have had positive consumer experiences with various city center touchpoints, such as stores, atmosphere, parks, and markets. Debenedetti, Oppewal and Arsel (2014) take an interpretive perspective to show that place familiarity, authenticity, and security enhance consumer place attachment in retail settings. Place familiarity refers to knowing a place intimately and being treated as a personal guest in a private setting, that is, experiencing conviviality - knowing and being known by people. It occurs through repeated access to 'backstage' areas, activities, and stories that allow people to become connected intimately with a place and with others. Place authenticity exists when people feel a place is genuine and irreplaceable; it is formed thanks to the people inhabiting the place, the performed activities, and the place's physical appearance. In this process, interpersonal exchanges with familiar people enhance authenticity and convey a sense of hominess (McCracken 1988). Finally, place security relates to comfort, support, and shelter, which are also salient in the experience of home (McCracken 1988). By providing a sense of protection from social aggression and intrusion, safe places can foster place attachment.

In the retail context, Debenedetti, Oppewal and Arsel (2014) observe that the overall experience of domesticity arises from the general atmosphere of a store, including its interpersonal relations. Eroglu and Michel (2018) extend the observations of Debenedetti, Oppewal and Arsel (2014) by uncovering a dark side of hominess and place attachment in retail settings. As people become more involved in social relationships in stores, they may lose their sense of consumer freedom and tend to avoid their treasured places. They may or may not continue to patronize the stores, depending on their experiences of interdependent freedom.

Though prior consumer research provides valuable insights on place attachment in commercial settings (Debenedetti, Oppewal and Arsel 2014), we continue to lack understanding of how place attachment operates in cities. Specifically, the interplay of attachment, emotions, and consumption remains understudied.

City identity and city attachment are both strong concepts related to the city as a place; and have elements that can be explored from a variety of perspectives from multiple basic and applied disciplinary perspectives. The foregoing discussion on city identities and city attachment thus suggests three research questions: 
1. How do consumers build city identities?

2. How are attachment styles manifested in city identity building?

3. What is the interplay of attachment and urban spaces with consumption in the process of city identity building?

We locate our study in Casablanca, Morocco, Africa. Casablanca is known in various ways, ranging from palpably physical experiences to media-shaped views. Partly, it is considered a romantic city thanks to the movie interpreted by Bogart and Bergman. It is also a modern business place in North Africa - a commercial and industrial hub. It is also a unique art deco city: French architects developed their most avant-garde ideas in Casablanca during the era of the French protectorate at the beginning of the 20th century.

\section{Method}

\section{Background}

Casablanca, well known from the movie of the same name, is the largest city in Morocco. It is the economic capital; it has about 4.2 million inhabitants and is strategically located near maritime routes. In 1912, it became a French protectorate. Since Morocco achieved independence in 1956, the city has been a symbol of modernity and dynamism in which sociocultural norms are less conservative than in other Moroccan cities (Newcomb 2009).

Contemporary Casablanca attracts $48 \%$ of Morocco's economic investment, $31 \%$ of its industrial units, and $38 \%$ of its industrial jobs (Belkadi 2015). The city employs 39\% of the active population of Morocco, and its harbor handles $55 \%$ of the country's external trade.

Casablanca offers a particular blend of cultural flows between Western and non-Western cultures. It is a modern Moroccan French-style city that hosts cultural events in collaboration with various foreign authorities. For example, the Indian embassy organized the Holi Festival (a festival of colors), and the African Month was organized at the Morocco Mall to celebrate sub-Saharan cultures. These cultural events enrich Casablanca's cultural diversity.

In 2016, Casablanca launched its brand and logo "wecasablanca" to position itself as a modern, attractive city, an investment hub for Africa, and a shopping destination (http://wecasablanca.com/we/demarche). This city branding, however, has generated some criticism. There are many social disparities in the city, with 72,000 households still living in shantytowns, 23\% without running water, and 55\% without sewers 
(Belkadi 2015). Casablanca also experiences traffic issues; the number of cars is predicted to multiply fourfold in the next 15 years.

Almost immediately after the launch of the 'wecasablanca' brand, several consumers reacted on social media and in the press, highlighting discrepancies between Casablanca branding and Casablanca residents' perceptions of their city. For instance, many posts on social media severely condemned Casablanca stakeholders for being willing to build a modern 'smart city' identity when Casablanca suffers from more basic issues, such as inadequate garbage collection (https://www.huffpostmaghreb.com/2016/10/24/casablanca-

marque $\mathrm{n}$ 12619250.html). In this study, we extend previous works that focused on city identity and examine residents' attitudes and emotions toward their city. We aim to understand how Casablanca residents build their city identities through their consumption experiences in various urban spaces.

\section{Method of Inquiry}

To answer our research questions, we employed a phenomenological approach. This approach emphasizes consumption experiences and consumers' lived experiences (Cherrier and Murray 2007; Pollio, Henley and Thompson 1997; Thompson, Locander and Pollio 1989) and is well suited in to explore consumers' bonds with places (Stedman 2003). In this study, we consider consumption experiences to occur along a continuum from ordinary to extraordinary experiences (Carù and Cova 2003).

The lead author conducted twenty-two phenomenological interviews in private places (i.e., informants' homes) and public places (i.e., cafés). Informants were selected according to established principles of variety and contrast (Miles and Huberman 1984); they ranged in age from 19 to 62 years old and had various sociocultural backgrounds. Table 1 details their profiles.

Through interviews, we sought to understand how informants perceived Casablanca's infrastructure, leisure activities, and features, as well as to discover their feelings and emotions about their city. We paid particular attention to informants' consumption experiences in Casablanca. Interviews ranged from 45 minutes to 2 hours; they were fully transcribed for analysis.

To complement this approach, we carried out participant and nonparticipant observations in Casablanca's streets, in various locations of the city, relating mostly to daily situations. With these observations, we aimed to capture in situ consumer residents' interactions with the city like public transportation, public places, and leisure activities. By using the participant-observation method, we had the advantage of gaining access 
to different areas of Casablanca and to the contexts in which experiences were taking place.

Table 1: Informants' Profiles

\begin{tabular}{|c|c|c|c|c|}
\hline Name & Gender & Age & Occupation & Education \\
\hline Abdelhamid & Male & $\begin{array}{l}54 \text { years } \\
\text { old }\end{array}$ & professor & $\mathrm{PhD}$ \\
\hline Ahmed & Male & $\begin{array}{l}48 \text { years } \\
\text { old }\end{array}$ & employee & High school \\
\hline Amine & Male & $\begin{array}{l}23 \text { years } \\
\text { old }\end{array}$ & student & Master's \\
\hline Halima & Female & $\begin{array}{l}49 \text { years } \\
\text { old }\end{array}$ & employee & Bachelor's \\
\hline Houria & Female & $\begin{array}{l}\text { 56- years } \\
\text { old }\end{array}$ & housewife & Bachelor's \\
\hline Ismail & Male & $\begin{array}{l}19 \text { years } \\
\text { old }\end{array}$ & student & High school \\
\hline Majdouba & Female & $\begin{array}{l}62 \text { years } \\
\text { old }\end{array}$ & therapist & Certificate \\
\hline Malika & Female & $\begin{array}{l}32 \text { years } \\
\text { old }\end{array}$ & housewife & Illiterate \\
\hline Maria & Female & $\begin{array}{l}32 \text { years } \\
\text { old }\end{array}$ & manager & Master's \\
\hline Meriem & Female & $\begin{array}{l}42 \text { years } \\
\text { old }\end{array}$ & housewife & Master's \\
\hline Mouna & Female & $\begin{array}{l}45 \text { years } \\
\text { old }\end{array}$ & manager & Master's \\
\hline Mourad & Male & $\begin{array}{l}55 \text { years } \\
\text { old }\end{array}$ & $\begin{array}{l}\text { doctor in } \\
\text { medicine }\end{array}$ & $\begin{array}{l}\text { Doctorate in } \\
\text { medicine }\end{array}$ \\
\hline Najat & Female & $\begin{array}{l}40 \text { years } \\
\text { old }\end{array}$ & housewife & Bachelor's \\
\hline Neil & male & $\begin{array}{l}20 \text { years } \\
\text { old }\end{array}$ & student & Bachelor's \\
\hline Nouria & female & $\begin{array}{l}52 \text { years } \\
\text { old }\end{array}$ & housewife & $\begin{array}{c}\text { Doctorate in } \\
\text { pharmacy }\end{array}$ \\
\hline Oumaima & female & $\begin{array}{l}19 \text { years } \\
\text { old }\end{array}$ & student & Bachelor's \\
\hline Rachida & female & $\begin{array}{l}27 \text { years } \\
\text { old }\end{array}$ & employee & Master's \\
\hline
\end{tabular}




\begin{tabular}{|l|c|c|c|c|}
\hline Name & Gender & Age & Occupation & Education \\
\hline Saida & female & $\begin{array}{c}20 \text { years } \\
\text { old }\end{array}$ & student & Bachelor's \\
\hline Soumia & female & $\begin{array}{c}35 \text { years } \\
\text { old }\end{array}$ & $\begin{array}{c}\text { beauty } \\
\text { therapist }\end{array}$ & High school \\
\hline Yamina & female & $\begin{array}{c}51 \text { years } \\
\text { old }\end{array}$ & housewife & Master's \\
\hline Yasmine & female & $\begin{array}{c}48 \text { years } \\
\text { old }\end{array}$ & manager & Master's \\
\hline Walid & male & $\begin{array}{c}19 \text { years } \\
\text { old }\end{array}$ & student & Bachelor's \\
\hline
\end{tabular}

The first researcher carried out the bulk of the fieldwork; she had intimate access to the field because she has lived in Casablanca since infancy. As recommended by Belk, Wallendorf and Sherry (1989), the four researchers first analyzed the data separately, both intratextually and intertextually, then together. This procedure aims to satisfy the criteria of trustworthiness.

Our data analysis relied on several elements. First, negotiations of consumers in distinct urban spaces (Castilhos and Dolbec 2018) were relevant, because they highlighted the many ideas, beliefs, preferences, values, and objectives related to these spaces. Second, to highlight the main perceived characteristics of spaces by residents, we relied on three assets of retail places listed by Debenedetti, Oppewal and Arsel (2014). Third, we drew the identification of emotions associated with place attachment from Scherer's (2005) categorization of emotions.

Our interpretation followed hermeneutical analysis principles, in line with the phenomenological approach (Thompson 1997; Thompson, Locander and Pollio 1989). This process reveals the meanings assigned by consumer residents, related to their lived experiences within the city, and it addresses the fragile balance between the 'spoken' and the 'unspoken' (Thompson, Pollio and Locander 1994). Our findings, which emerge from the data set as a whole, are illustrated with short extracts that situate residents in their contexts. We present selected vignettes from the data that best illustrate the observed phenomenon.

\section{Findings}

Our data analysis reveals that consumer residents build Casablanca identities through a blend of emotionally infused consumption experiences in distinct urban spaces, using the characteristics of these specific urban spaces. Our data analysis also identifies five city identity-building 
processes, related to five city identities:(1) City of Escape, (2) Busy Isolating City, (3) Clustering City, (4) Small City, and (5) Dark City.

\section{Building a City of Escape Identity}

Building an identity of a City of Escape derives from emancipating consumption experiences, especially during collective experiences, like festivals, public demonstrations, as Oumaima expresses:

This year Casablanca ran an extraordinary event, which was the Holi festival in October. It was my first time; I had never attended a festival before. It was extraordinary; there were colors everywhere, music and a very good ambiance. This was a very well-organized event; I met many people, many of them shared the same passion for music. I had a lot of fun; this was an unforgettable day. (Oumaima, female, 19 years old)

Here, Oumaima evokes the unique emancipating character of Casablanca. She feels positive emotions such as amusement when she remembers 'a lot of fun.' Oumaima also suggests a form of admiration as she highlights the good organization of the event and describes the 'unforgettable' character of the festival.

In her interview, Oumaima also tells how, as a young child, she was living in a small town in which most social gatherings were of traditional Moroccan style, and held in homes. As a young girl, she scarcely went out, taking into account the local sociocultural norms that regulate women's and girls' presence in public spaces (Mernissi 2010). Living in Casablanca allows her to be in contact with unknown people and make new friends. Casablanca offers Oumaima the opportunity to escape from some of the norms related to women's presence and behaviors in a public space.

During our fieldwork, we observed that festivals in Morocco were relatively safe events. Security is increased through the deployment of many police agents and soldiers. The Holi Festival hosts many Moroccan families and young adults. Many young women, like Oumaima, enjoy the opportunity provided at the Holi Festival to go out at night and dance in a public place. In this way, the festival becomes an ephemeral space of consensus (Kozinets 2002). That is, as women consume festivals in Casablanca, they experience forms of escape. In Oumaima's own words, she feels 'safe' and 'secure'. This observation shows that the secure character of the festival induces a deep attachment to the city (Debenedetti, Oppewal and Arsel 2014).

Through this extraordinary consumption experience (Carú and Cova 2003), Oumaima developed a particular attachment to Casablanca. 
She claims, 'I like to live in Casablanca. There are more opportunities for me to go out [than in my former town]'. When she compares Casablanca to her city of origin (in rural Morocco), Oumaima expresses an attachment of ideological rootedness (Hummon 1992) that is associated with positive emotions such as admiration and amusement. Other female informants, such as Rachida and Soumia, express similar senses of security and escape infused with amusement, as they describe their excursions to the Ramadan trade fair or malls.

This sense of secure escape also arises through the consumption of additional public spaces. Abdelhamid, a university professor, remembers the street demonstrations in Casablanca that followed the Arab Spring in 2011. He remembers his will to demonstrate while he was afraid to express his voice publicly. He says:

The demonstration [in Casablanca during the Arab Spring] was peaceful. We would walk slowly, holding each other's hands to make sure that nobody would leave the procession and make troubles. We would chant our will for change. The police and security forces would let us speak out our minds. (Abdelhamid, male, 54 years old)

Abdelhamid talks with pride about how the demonstration was run. Before the demonstration, he feared violent repression from the security forces. But that day, he did not observe any misbehavior. Abdelhamid's participation in the Arab Spring demonstration reinforced his belief that he can securely express his opinions in Casablanca's public spaces and escape from specific social norms. Abdelhamid lived in France during his university studies. His attachment to Casablanca is ideological, in that he consciously chose to settle there. Like Oumaima, he compares Casablanca with other cities such as El Jadida or Fès, where residents are more conservative (Newcomb 2009). Unlike Oumaima, however, his attachment is not based on amusement but rather on serious relief (Scherer 2005).

Thus, participating in the Holi Festival, the Ramadan trade fair, and the Arab Spring demonstrations provide a 'temporary liberation from the social order' (Castilhos and Dolbec 2018, p. 161). Oumaima, Abdelhamid, Soumia, and Rachida are building the specific city identity of City of Escape. This identity relates to ideological rootedness (Hummon 1992) that arises from a sense of security (Debenedetti, Oppewal and Arsel 1994). Informants who associate with this identity express emotions such as amusement and relief (Scherer 2005). 


\section{Building a Busy Isolating City Identity}

Although many large cities around the world are characterized by crowded spaces, some consumer residents can manage to find spaces in which they can be isolated from the crowd. From these solitary consumption experiences, they build Busy Isolating City identities. Several informants see Casablanca as a busy city. Neil, a young Moroccan male student, however, has found a specific space in which he can isolate himself through ordinary experiences of consumption (Carú and Cova 2003). Neil likes to go to the beach in the early morning:

I have the chance to live about not far from the beach so I can feel secure because my parents can immediately come if I have any problems. I like to go and exercise at 7:30 in the morning every Saturday instead of sleeping. But I think that it is more than that, because driving near the sea when the sun rises is something magical. You are driving alone, you look at the ocean, you listen to your favorite pop music and you are lost in your thoughts, you look at other people running on the boardwalk and there is nobody on the roadway. In that way, you enjoy so much because you know these kinds of moments are priceless in a city like Casablanca. You know that in less than two hours, it will be impossible to drive and within four hours it will be suicide [to drive in Casablanca]. I saw many sunrises even in the Sahara but no one equals the ones in Casablanca. (Neil, male, 20 years old)

Here, Neil recognizes the busy character of Casablanca. Driving induces negative emotions such as irritation and stress. Neil, however, also appreciates the authentic character (Debenedetti, Oppewal and Arsel 2014) of Casablanca - its shore, its beach, and the sunrise in particular. In his interview, Neil expresses that experiencing an early morning - while alone on the beach - instills a deep sense of admiration, passion, magic, and beauty for what the city can offer. He seems to invoke emotions such as serenity and contentment. For Neil, these moments help him to 'get back into [his] stressful life.' He notes the ephemeral character of the sunrise and his related isolation in Casablanca. Such a place (i.e., the beach) and time (i.e., 7:30 a.m.), however, can provide emotions that enable an ideological attachment to his city. Thus, his attachment is conscious and appears as an outcome of a special blend of time and space.

Several female informants, such as Najat and Yamina, describe with delight their early daily walks on the beach. They stress the importance of going to the beach early. They contend that after 10:00 
a.m., it gets difficult for women to walk on the beach without facing comments and glares.

For Malika, isolation and serenity may occur at 8:00 p.m. in her next-door supermarket, 'when there are not so many people, and no noise.' Her attachment to Casablanca is more of an everyday rootedness; she was born in Casablanca and has little opportunities to think about moving to another city. Malika also notes 'I get tired in the supermarket, I get easily exhausted. It's big! There are too many people and too much noise.' Malika, like Neil and Yamina, values her isolated moments because she knows that they are ephemeral. Thus, solitary moments, which appear as a subversion of the busy, vibrant character of Casablanca, may be limited in time. The contrast between peak/busy and low-traffic/isolating times allows our informants to build a type of city identity that reflects these contradictory dimensions.

Accordingly, the Busy Isolating City identity is fostered not only by a place's authentic and secure character (Debenedetti, Oppewal and Arsel 2014) but also by its blend of isolating and busy character. In this identity, positive emotions dominate, and residents are strongly attached to Casablanca through ideological rootedness (Hummon 1992).

\section{Building a Clustering City Identity}

Our data analysis reveals that city identity building may relate to a strong form of clustering. Informants who developed a clustering city identity perceive Casablanca as a set of spaces where they experience either positive emotions, or negative emotions. These informants choose places where they feel comfortable and try to avoid places where they feel unwelcome. For example, Saida, a young law student from a lowermiddle-class background, reminds her emotions when she shops in supermarkets:

Sometimes, [supermarket] employees behave as if they did not listen to us; they pretend to speak to their colleagues so that they don't have to speak to us. Casablanca is like that! We are Moroccans: we only consider someone through the way he's dressed. If it's someone, a Sidi, someone from the upper class, who talks to him, there will be a 'good day Sidi!', a warm welcome. But if it's an ordinary person, the employee won't even give a bit of his time to him. (Saida, female, 20 years old)

Here, Saida manifests anger and irritation that she attributes mainly to employees' behaviors and attitudes. Past research suggests that employees behave according to scripted roles that aim to reinforce homogeneity among customers (Debenedetti, Oppewal and Arsel 2014). 
As exemplified in prior literature, consumers are also concerned about how other consumers may regard manners in shared spaces (Üstuner and Holt 2010). Saida notes:

People who go to supermarkets are special...They are...I won't tell! You can't even breathe next to them. You must pay attention. Any wrong move would give them an opportunity to look at you in this weird way, like you just committed a crime and they think: 'Where does she come from?' (Saida, female, 20 years old)

Thus, Saida feels that employees and customers play a fundamental role in reinforcing the norms of behaviors. In her interview, she talks about her strong accent and her clothes and she believes that the supermarket employees do not consider her belonging to the supermarket targeted consumer group (for a similar finding in the context of early days of supermarket shopping in India, see Dholakia and Sinha 2005).

Saida likes to patronize traditional shopping spaces in which 'people are normal. They behave normally. You feel comfortable. Nobody looks at you.' Thus, whereas supermarkets provoke Saida's anger and irritation, she feels relaxed in traditional stores. The longing associated with traditional markets (Atik and Vicdan 2012) fosters a sense of everyday rootedness (Hummon 1992). Saida has had little opportunity to travel and compare Casablanca to other cities in Morocco and throughout the world.

Similarly, Ahmed, a 48-year-old school clerk, claims that he tries to avoid supermarkets because it is more for the upper class... Prices are often too expensive for me.' As a result, he hardly goes to the supermarket and prefers to patronize local markets.

The Clustering City identity of Casablanca is also built in segregating and market spaces (Castilhos and Dolbec 2018), such as private clubs or restaurants. For instance, Mourad, a 55-year-old doctor, likes to go to his private club on the beach, where he can 'drink a glass of wine' and his wife can 'go to the [private] beach and swimming pool in her bikini.'

Maria recognizes that Casablanca residents are often 'trapped in their own [social] groups.' She was born in Casablanca and she has lived abroad for more than 15 years, after high school, but she has now settled back in Casablanca. She defines herself as curious and tries to navigate across distinct worlds:

I like to meet people with different lifestyles. I now know many things in Casablanca that I didn't know when I was a kid. My friends are all very different... I like to go to the Abattoire [ancient 
slaughterhouse converted into an art gallery and concert hall] with my artist friends... I still meet with my school friends, and we go out dancing or eat in fancy restaurants. But they don't know about my artist friends and they don't go to the Abattoire... Lately, I started to learn to surf. At my age! Most surfers are kids. It's difficult but I don't care. (Maria, female, 32 years old)

Maria recognizes that she comes from a bourgeois family and was kept away from many groups of Casablanca residents when she was younger. Today, she likes to switch from one group to the other and 'learn so much' from the residents she meets. She also confesses that she cannot have a party with all her different friends together 'because they are too different from one another.' For Maria, Casablanca is a clustering city that offers many opportunities to learn about people. Her attachment to Casablanca indicates ideological rootedness.

The 'cultural enclaves' with homogeneity of 'cultural backgrounds' (Tanulku 2012) enhance Meriem's, Mourad's, and Saida's attachments to their city. Saida tends to avoid supermarkets but seems to like Casablanca's traditional stores. Mourad enjoys the exclusionary character of certain spaces in Casablanca (i.e., private clubs and restaurants). Maria moves among these various enclaves. Maria, Meriem, and Mourad developed attachments to Casablanca by being influenced by their various experiences of distinct cities in the world. Saida and Ahmed have attachments to their city that relate to everyday rootedness (Hummon 1992). These distinct attachments, emanating from consumption experiences in clustering spaces in Casablanca, facilitate the building of a Clustering City identity; they are associated with both positive and negative emotions.

\section{Building a Small City Identity}

Our data analysis demonstrates how consumer residents foster interpersonal relationships within small groups of relatives or friends, and thus, develop the sense of knowing everybody in the city. We call this identity a Small City identity.

One illustration of this identity type is Mouna's experiences of cafés. Casablanca has several cafés that target the business elite. In such places, the personnel perform scripted roles (Debenedetti, Oppewal and Arsel 2014) that aim to assist loyal customers. Mouna describes her morning experiences in her favorite café:

I like to go every morning to the same café in town, near my office. I like it so much! This is my morning ritual. I always have my breakfast there, after I drop the kids at school [and before going to 
work]. I know everybody. The waiters know exactly what I like [to order]. They warn me if my parking time is over. I always meet the same persons: a couple of businessmen, a girlfriend... They always ask me to sit with them. I never eat alone, and I like it (Mouna, female, 45 years old)

Here, Mouna expresses emotions such as happiness (likes going to the café), associated with serenity (a morning ritual). These emotions are facilitated by the café's security and familiarity (Debenedetti, Oppewal and Arsel 2014). During our fieldwork, we also observed that Mouna knows most of the morning customers in this café. They are often related: cousins, neighbors, or business relations. The café resembles a very cohesive group of people with similar backgrounds. The people at the café often have comparable family backgrounds, send their children to the same private school, and have attended universities abroad. There is a strong sense of social reproduction (Üstuner and Holt 2007).

This cohesion is preciously guarded through the behaviors of the café's personnel. Waiters seat newcomers in specific places, depending on their relationships with the core clientele. They try to maintain a form of homogeneity inside the café. The outdoor terrace may be more eclectic in terms of clientele. Behaviors are fostered through specific arrangements that facilitate the development of scripted roles (Sherry et al. 2001), interactions with paid employees, and interactions with other customers (Debenedetti, Oppewal and Arsel 2014). The owner of Mouna's café tells: 'From the beginning, I put emphasis on having a loyal clientele, and I worked a lot to train my employees on how to serve them.' The owner of the café is a former businesswoman, who worked for 20 years in a bank. She belongs to the same social group as her core clientele. She has tailored the behavioral norms that pervade the café to adapt to her customers' expectations.

We observed that most conversations in Mouna's café are aimed at tightening the social bonds that link these customers together. They exchange information about who started a new business or who recently married whom, but they also tell stories about their grandfathers' childhoods. Conversations aim to enhance the cohesion of the group (Castilhos and Dolbec 2018; Üstuner and Holt 2007). Nouria conveys a sense of cohesion: 'In Casablanca, we know everybody, and we know everything on everybody. It's impossible to go to a place [restaurant, store, café] without meeting somebody we know.' She compares Casablanca to Paris, where her daughter lives and where she can walk around for a full day without meeting anybody she knows. The cohesion within the café, 
reinforced by consumer residents' discourses, instills a sense of 'small village' into the big city of Casablanca.

Other groups find additional spaces that foster a Small City identity. For instance, many sub-Saharan migrants patronize Souk Senegal, a market district that provides many services tailored for sub-Saharan consumers. Ruth, a Beninese student in Casablanca, likes to shop and go to the hairdresser in Souk Senegal, where she feels 'like at home.' She reports similar feelings of hominess (McCracken 1988) and serenity when she goes to Catholic mass in Casablanca's center. There, she meets friends and acquaintances with similar sub-Saharan backgrounds, which enhances social reproduction.

Cafés, stores, and restaurants gather cohesive groups through security and familiarity (Debenedetti, Oppewal and Arsel 2014). Our findings show that, when taken as a whole, these spaces foster a Small City identity embedded within Casablanca.

The type of attachment related to Casablanca as a Small City has two sides. On the one hand, consumer residents, such as Mouna, show forms of strong ideological rootedness (Hummon 1992). They have traveled and lived abroad and find serenity in living among a small cohesive community. On the other hand, several informants noted forms of place relativity (Hummon 1992). Living in a Small City implies losing forms of intimacy. Ismail, a young 19-year-old student, complains:

It's difficult for me to have a date with a girl. Because everybody at school will know about it. Then, if I try to go out with her [in secret], I will meet somebody I know, for sure. And he will repeat it to everybody... And if it doesn't work with the girl, everybody will gossip. (Ismail, male, 19 years old)

Ismail expresses forms of irritation; though he claims that he likes to live in Casablanca and he will miss his life next year when he will be abroad for his studies, he also notes 'I am waiting to live abroad to have a girlfriend.' Thus, Ismail has an ambivalent attitude toward Casablanca and demonstrates a form of place relativity attachment (Hummon 1992).

\section{Building a Dark City Identity}

The Dark City identity relates to the consumption of public spaces as described by Castilhos and Dolbec (2018). Informants who built a dark city identity perceive Casablanca as having many negative aspects that overcome the positive dimensions of the city. Informants who built a dark city identity nevertheless demonstrate forms of attachment to their city. The Dark City identity is characterized by a sense of dirtiness, crowding, and insecurity, as expressed by Walid: 
When I arrived in Casablanca, I noticed that it is not a city like the others. It is so polluted! I come from a very neat, clean city: Rabat. Casablanca is a dirty city. Garbage everywhere: on the sidewalks, on the streets. Garbage bins overflow and spread a nauseating smell. (Walid, male, 19 years old)

Walid's words are quite sharp; they reveal some negative emotions toward Casablanca. As compared to Rabat, the administrative capital, Walid thinks that Casablanca residents are 'not educated to environmental issues.' Walid moved to Casablanca to attend college, though he would have loved to stay in Rabat. In this quote, Walid clearly expresses a form of non-attachment to Casablanca that is place alienation (Hummon 1992).

The sense of crowding is salient in Amine's quote too. Amine, a Casablanca-born student, describes his morning drive to the university:

I leave home. The bus is late. I wait for more than 20 minutes. It comes. A dozen students are waiting. We fight to get on the bus first and have a seat. I stand during the whole trip, which is about 30 minutes. I am stuck at the door. The bus is like a human ZIP file [compressed items]. We start off. Thanks God! I have my earphones and a radio. I turn the sound loud. So I don't hear the noise, the fights and quarrels with the driver. I try to forget about everyone. I finally reach college. But what? I am totally exhausted and the day is only beginning. (Amine, male, 23 years old)

Amine feels negative emotions to his ride on public transportation. In this quote, he expresses forms of dissatisfaction, stress, and irritation.

Finally, insecurity contributes to building a Dark City identity to Casablanca. Walid, as well as Amine, fear that they might be robbed when they walk in the streets of Casablanca. Houria, a 56-years-old housewife, does not know if she has 'to pay attention to her step or her bag' when she walks in the street. Rachel, who recently settled back into Casablanca after living 15 years in Paris and New York, complains that 'there is not much place to walk [in Casablanca], except the beach.'

The Dark City identity, however, can also be related to ambivalent emotions. As expressed by Majdouba even though there are aspects that she does not appreciate of Casablanca, she still feels a strong city attachment:

I would never recommend that anyone live in Casablanca. It's too complicated. The stress... But you know, I like Casablanca. I don't know why but after one month abroad, I miss Casablanca. I am always happy to come back [after my summer holidays] [laughs]... (Majdouba, female, 62 years old) 
Majdouba reveals her deep attachment to Casablanca 'in my guts.' She was born in Casablanca, lived for a couple of years in France, and decided to come back to live in the city in her twenties. Her emotions toward Casablanca blend admiration, compassion, contentment, and desperation (Scherer 2005).

Thus, the Dark City identity relates to non-attachments, as described in literature (Hummon 1992). Walid and Amine exhibit forms of place alienation; they express dislike for Casablanca and feelings of estrangement. Majdouba presents a blend of ambivalent emotions. She deplores the negative characters of the city but feels compassion. Her attachment to Casablanca is more of a place relativity type.

Surprisingly, we did not observe any form of placelessness, the other form of non-attachment (Hummon 1992). Thus, it seems that Casablanca does not leave consumer residents indifferent.

\section{Discussion}

Our study uncovers the dynamics of city identity building through consumption behaviors in specific city spaces, pervaded with global and local dynamics. Casablanca residents report numerous consumption experiences related to emancipating spaces (festivals), public spaces (beach), segregating spaces (private clubs), and market spaces (cafés, restaurants). This blend of various consumption experiences, which is emotionally infused, allows consumer residents to construct identities and various attachment styles to their city.

Our study shows how each of the five city identity types relate to consumer residents' experiences in distinct spaces. The building of a City of Escape identity implicates consumption experiences in emancipating and public spaces, where consumer residents emancipate themselves from social norms. The Busy Isolating City identity is constructed through consumption in public spaces, where consumer residents find refuge from the crowd. The Clustering City identity is constructed in specific market spaces and segregating spaces that are sociocultural enclaves (Tanulku 2012). The Small City identity relates to a sense of hominess (McCracken 1988) that exists in market and segregating spaces, where consumer residents feel that they 'know everybody.' The Dark City identity derives from consumption behaviors in public spaces that are embedded with significant negative outcomes.

Overall, our data analysis answers our three research questions: (1) How do consumers build identities with their cities? (2) How are attachment styles manifested in city identity building? (3) What is the interplay of attachment, spaces and consumption in the process of city 
identity building? In response, our findings are also threefold. First, they show how consumer residents build identities for their city, derived from their consumption experiences and their uses of the various characteristics of urban spaces and places. Second, they show how attachment styles and related emotions pervade the building of city identities. Third, they illustrate the central role of space in the city identitybuilding process and development of attachment. Table 2 presents our main findings.

Table 2: Main Findings

\begin{tabular}{|c|c|c|c|c|c|}
\hline $\begin{array}{l}\text { City } \\
\text { identity }\end{array}$ & $\begin{array}{l}\text { Perceived main } \\
\text { characteristics } \\
\text { (Debenedetti, } \\
\text { Oppewal and } \\
\text { Arsel 2014) }\end{array}$ & $\begin{array}{l}\text { Main } \\
\text { attachment } \\
\text { type } \\
\text { (Hummon } \\
\text { 1992) }\end{array}$ & $\begin{array}{l}\text { Main emotions } \\
\text { (Scherer 2005) }\end{array}$ & $\begin{array}{l}\text { Related } \\
\text { spatial types } \\
\text { (Castilhos and } \\
\text { Dolbec 2018) }\end{array}$ & $\begin{array}{l}\text { Example of } \\
\text { consumer } \\
\text { experience }\end{array}$ \\
\hline $\begin{array}{l}\text { City of } \\
\text { escape }\end{array}$ & Security & $\begin{array}{l}\text { Ideological } \\
\text { rootedness }\end{array}$ & $\begin{array}{l}\text { Positive } \\
\text { emotions: } \\
\text { Amusement, } \\
\text { admiration, } \\
\text { relief }\end{array}$ & $\begin{array}{l}\text { Emancipating } \\
\text { space } \\
\text { Public space }\end{array}$ & $\begin{array}{l}\text { Experiences } \\
\text { related to public } \\
\text { facilities: } \\
\text { Participating in a } \\
\text { festival, } \\
\text { Demonstrating in } \\
\text { the streets }\end{array}$ \\
\hline $\begin{array}{l}\text { Busy } \\
\text { isolating } \\
\text { city }\end{array}$ & $\begin{array}{l}\text { Authenticity } \\
\text { Security }\end{array}$ & $\begin{array}{l}\text { Ideological } \\
\text { rootedness }\end{array}$ & $\begin{array}{l}\text { Positive } \\
\text { emotions: } \\
\text { Contentment, } \\
\text { serenity }\end{array}$ & Public space & $\begin{array}{l}\text { Experiences } \\
\text { related to public } \\
\text { facility: Walking } \\
\text { on the beach }\end{array}$ \\
\hline $\begin{array}{l}\text { Clustering } \\
\text { identity }\end{array}$ & $\begin{array}{l}\text { Familiarity } \\
\text { Security }\end{array}$ & $\begin{array}{l}\text { Everyday } \\
\text { rootedness } \\
\text { Ideological } \\
\text { rootedness }\end{array}$ & $\begin{array}{l}\frac{\text { Negative }}{\text { emotions: }} \\
\text { Anger, irritation } \\
\frac{\text { Positive }}{\text { emotions: }} \\
\frac{\text { Joy, }}{\text { contentment }}\end{array}$ & $\begin{array}{l}\text { Market space } \\
\text { Segregating } \\
\text { space }\end{array}$ & $\begin{array}{l}\text { Experiences } \\
\text { related to market } \\
\text { provided } \\
\text { resources: } \\
\text { Shopping in a } \\
\text { supermarket, } \\
\text { Consuming in a } \\
\text { private club }\end{array}$ \\
\hline Small city & $\begin{array}{l}\text { Familiarity } \\
\text { Security }\end{array}$ & $\begin{array}{l}\text { Ideological } \\
\text { rootedness } \\
\text { Place } \\
\text { relativity }\end{array}$ & $\begin{array}{l}\frac{\text { Negative }}{\text { emotions: }} \\
\text { Irritation } \\
\text { Positive } \\
\text { emotions: } \\
\text { Happiness, } \\
\text { serenity }\end{array}$ & $\begin{array}{l}\text { Market space } \\
\text { Segregating } \\
\text { space }\end{array}$ & $\begin{array}{l}\frac{\text { Experiences }}{\text { related to public }} \\
\frac{\text { facilities: }}{\text { Patronizing a }} \\
\text { district } \\
\frac{\text { Experiences }}{\text { related to market }} \\
\text { provided } \\
\text { resources: } \\
\text { Patronizing a } \\
\text { café }\end{array}$ \\
\hline
\end{tabular}




\begin{tabular}{|c|c|c|c|c|c|}
\hline $\begin{array}{l}\text { City } \\
\text { identity }\end{array}$ & $\begin{array}{l}\text { Perceived main } \\
\text { characteristics } \\
\text { (Debenedetti, } \\
\text { Oppewal and } \\
\text { Arsel 2014) }\end{array}$ & $\begin{array}{l}\text { Main } \\
\text { attachment } \\
\text { type } \\
\text { (Hummon } \\
\text { 1992) }\end{array}$ & $\begin{array}{l}\text { Main emotions } \\
\text { (Scherer 2005) }\end{array}$ & $\begin{array}{l}\text { Related } \\
\text { spatial types } \\
\text { (Castilhos and } \\
\text { Dolbec 2018) }\end{array}$ & $\begin{array}{l}\text { Example of } \\
\text { consumer } \\
\text { experience }\end{array}$ \\
\hline Dark city & $\begin{array}{l}\text { Familiarity } \\
\text { (In)security }\end{array}$ & $\begin{array}{l}\text { Place } \\
\text { alienation } \\
\text { Place } \\
\text { relativity }\end{array}$ & $\begin{array}{l}\frac{\text { Negative }}{\text { emotions: }} \\
\text { Hatred, disgust, } \\
\text { dissatisfaction, } \\
\text { stress, irritation } \\
\text { Positive } \\
\text { emotions: } \\
\text { Admiration, } \\
\text { compassion, } \\
\text { desperation }\end{array}$ & Public space & $\begin{array}{l}\text { Experiences } \\
\text { related to public } \\
\text { facility: Using } \\
\text { public } \\
\text { transportation }\end{array}$ \\
\hline
\end{tabular}

We derive two main contributions from our findings. The first relates to place identities and responds to the call for a better understanding of city identity building (Kavaratzis and Hatch 2013) and global connectivity (FIrat 2016; Sarkar 2019). Previous research suggested that place identity is co-constructed by multiple interpretations and perceptions of cities (Casakin, Hernández and Ruiz 2015). Most qualitative literature in the past, however, focused on one specific identity, built by multiple stakeholders (Brown, McDonagh and Shultz II 2013). Our study extends such knowledge to show how individual consumer residents can create multiple, ambivalent city identities. It shows that various characteristics of urban places and spaces foster or limit the building of specific identities.

Furthermore, our research sheds new light on the complexity of city identity building (Wester-Heber 2004). Although past research noted the dynamics of city identity building (Karavanis and Hatch 2013), it failed to examine how city identities are fostered or limited. Our findings suggest that time is an important factor: urban places can display differing characteristics over the course of a day. A single consumer resident may build several ambivalent city identities. For instance, Neil ascribes a Busy Isolating City identity to Casablanca in the early morning, but later in the day, he perceives a Dark City identity.

Our second theoretical contribution relates to place attachment (Debenedetti, Oppewal and Arsel 2014). This study uncovers the interplay of negative and positive emotions with place attachment in the process of identity building. These interplays are presented in Figure 1.

Further, prior research suggested that positive characteristics, like perceived authenticity, familiarity, and security favor place attachment (Debenedetti, Oppewal and Arsel 2014). Our findings show that consumer residents' attachments to cities depend not only on positive perceived characteristics of the city but also, paradoxically, on negative perceived 
characteristics, like insecurity. Previous studies have identified paradoxes related to city branding; for example, previously identified as 'awful' cities such as Belfast can attract consumers (Brown, McDonagh and Shultz II 2013). Our findings extend such works; they show that consumer residents can develop strong forms of attachment to cities, despite their negative characteristics, when their consumption experiences relate to ambivalent emotions toward a city, like compassion, desperation, and admiration.

Figure 1: Interplays of emotions and place attachments in city identity building

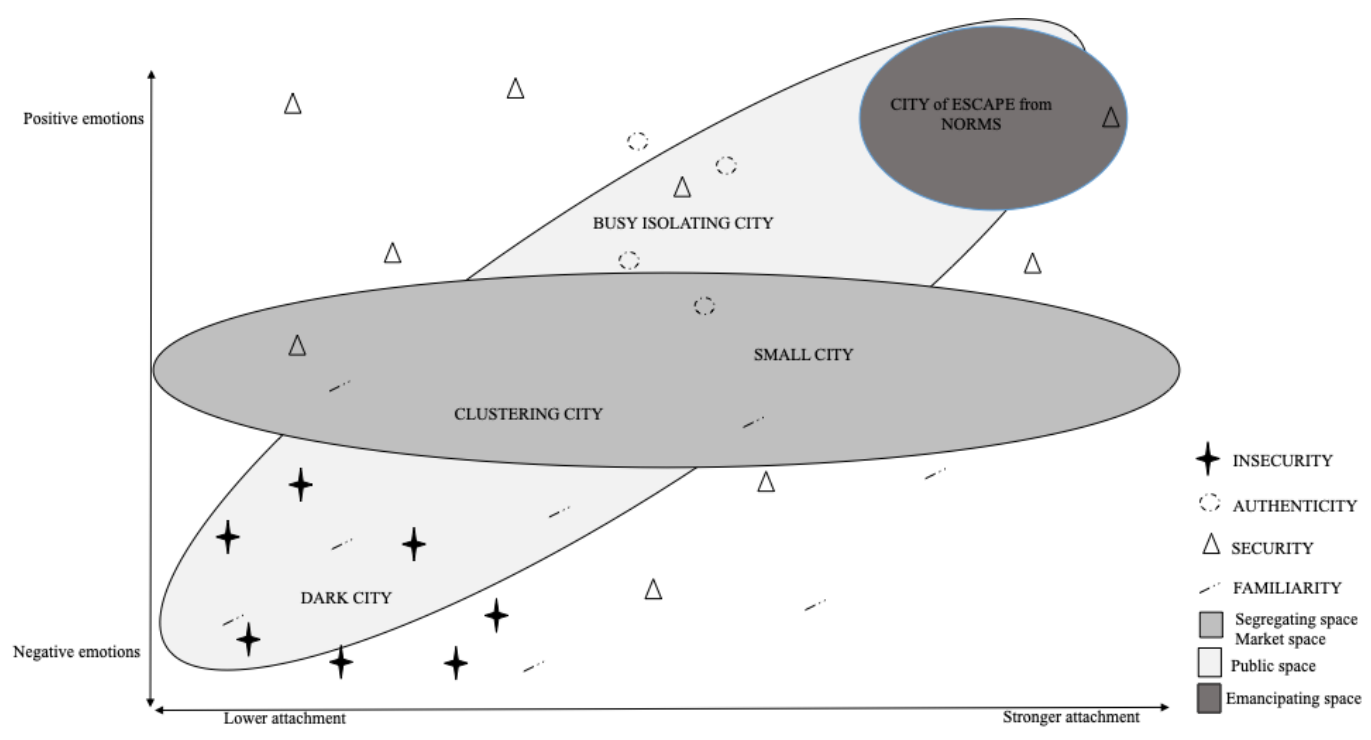


Beyond these theoretical implications, our research highlights implications for public authorities. The results reveal the multiplicity of city identities and their interplay with city attachment styles. These observations invite researchers and marketers to rethink city identity strategies. In conceiving city branding strategies, public authorities should be attentive to highlighting the specific characteristics that make their cities 'emotionally' different from their 'city competitors.' City branding should leverage specific emotions to foster specific city identities. For instance, Casablanca brand managers already focus on several remarkable places and events in Casablanca (festivals, the art deco center, the Shop in Casablanca event). They could reinforce their branding strategies by using emotional campaigns that reinforce consumers' attachments and emotions, such as admiration or compassion.

Our study has some limitations that open avenues for further research. First, we limited our investigation to Casablanca consumer residents. Researchers could extend our investigation to tourists, expatriates, and other stakeholders (companies, not-for-profit organizations, potential investors). Second, we limited our study to city identities; it may be interesting to pinpoint how city identities and consumer residents' identities influence each other and evolve. 


\section{References}

Atik, Deniz and Handan Vicdan (2012), "The Interplay of Culture(s) of Freedom in the Bazaars of Italy and Turkey," Journal of International Consumer Marketing, 24, 100-18. https://doi.org/10.1080/08961530.2012.650141

Belk, Russell W., Melanie Wallendorf and John F.Sherry Jr. (1989), "The Sacred and the Profane in Consumer Behavior: Theodicity on the Odyssey," Journal of Consumer Research, 16, 1-38. https://doi.org/10.1086/209191

Belkadi, Ezzohra (2015), "Place Marketing: The Brand Image of Casablanca," International Journal of Innovation and Applied Studies, 13 (3), 704-14.

Brown, Stephen, Pierre McDonagh and Clifford J. Shultz II (2013), "A Brand so Bad It's Good: The Paradoxical Place Marketing of Belfast," Journal of Marketing Management, 29 (11-12), 1251-79. https://doi.org/10.1080/0267257X.2013.796321

Carú, Antonella and Bernard Cova (2003), "Revisiting Consumption Experience: A More Humble but Complete View of the Concept," $\begin{array}{llll}\text { Marketing Theory, } 32 & \text { 267-86. }\end{array}$ https://doi.org/10.1177/14705931030032004

Casakin, Herman, Bernardo Hernández and Cristina Ruiz (2015), "Place Attachment and Place Identity in Israeli Cities: The Influence of City Size," Cities, 42, 224-30. https://doi.org/10.1016/j.cities.2014.07.007

Castilhos, Rodrigo B. and Pierre-Yann Dolbec (2018), "Conceptualizing Spatial Types: Characteristics, Transitions, and Research Avenues," Marketing Theory, 18 (2), 154-68. https://doi.org/10.1177/1470593117732455

Cherrier Hélène and Jeff B. Murray (2007), "Reflexive Dispossession and the Self: Constructing aProcessual Theory of Identity," Consumption, Markets \& Culture, 10 (3), 1-29. https://doi.org/10.1080/10253860601116452

Debenedetti, Alain, Harmen Oppewal and Zeynep Arsel (2014), "Place Attachment in Commercial Settings: A Gift Economy Perspective," Journal of Consumer Research, 40 (5), 904-23. https://doi.org/10.1086/673469 
Dholakia, Nikhilesh and Deniz Atik (2019), "The World is Not Simple: Connectivity, Complicity, Complexity," Markets, Globalization \& Development Review, 4 (4). https://doi.org/10.23860/MGDR-2019-04-04-01

Dholakia, Nikhilesh and Piyush Kumar Sinha (2005), "Observations on observation in India's dynamic urban markets", Forum Qualitative Sozialforschung/Forum: Qualitative Social Research, 6 (1). https://doi.org/10.17169/fqs-6.1.519

Droseltis, Orestis and Vivian L. Vignoles (2010), "Toward an Integrative Model of Place Identification: Dimensionality and Predictors of Intrapersonal-Level Place Preferences," Journal of Environmental Psychology, 30, 23-34. https://doi.org/10.1016/j.jenvp.2009.05.006

Eroglu, Sevgin and Géraldine Michel (2018), "The Dark Side of Place Attachment: Why do Customers Avoid their Treasured Stores?," Journal of Business Research, 85, 258-70. https://doi.org/10.1016/.j.jbusres.2018.01.009

Firat, A. Fuat (2016), "The Dynamics of the Local and the Global: Implications for Marketing and Development," Markets, Globalization \& Development Review, 1 (1), Article 4. https://doi.org/10.23860/MGDR-2016-01-01-04

Fried, Marc (1963), "Grieving for a Lost Home," in The Urban Condition: People and Policy in the Metropolis, Leonard J. Duhl, ed. New York: Basic Books, 151-71.

Giuliani, M. Vittoria (2003), "Theory of Attachment and Place Attachment," in Psychological Theories for Environmental Issues, M. Bonnes, T. R. Lee and M. Bonaiuto, ed. Aldershot: Ashgate, 137-70.

Giuliani, M. Vittoria and R. Feldman (1993), "Place Attachment in a Developmental and Cultural Context," Journal of Environmental Psychology, 13, 267-74. https://doi.org/10.1016/S0272-4944(05)80179-3

Hernández, Bernardo, M. Carmen Hidalgo, M. Esther Salazar-Laplace and Stephany Hess (2007), "Place Attachment and Place Identity in Native and Non-Natives," Journal of Environmental Psychology, 27, 310-19. https://doi.org/10.1016/.j.jenvp.2007.06.003

Hummon, David M. (1992), "Community Attachment, Local Sentiment and Sense of Place," in Place Attachment, S. M. Low and I. Altman, ed. New York and London: Plenum, 253-77. 
Insch, Andrea and Magdalena Florek (2010), "Place Satisfaction of City Residents: Findings and Implications for City Branding," in Toward Effective Place Brand Management: Branding European Cities and Regions, G. J. Ashworth and M. Kavaratzis, ed. Cheltenham, UK and Northampton, MA, USA: Edward Elgar, 191-204.

Kalandides, Ares (2011), "The Problem with Spatial Identity: Revisiting the "Sense of Place," Journal of Place Management and Development, 4 (1), 5-8. https://doi.org/10.1108/17538331111117142

Kavaratzis, Mihalis and Mary Jo Hatch (2013), "The Dynamics of Place Brands: An Identity-Based Approach to Place Branding Theory," $\begin{array}{llll}\text { Marketing Theory, } & 13 & \text { (1), }\end{array}$ https://doi.org/10.1177/1470593112467268

Kozinets, Robert V. (2002), "Can Consumers Escape the Market? Emancipatory Illuminations from Burning Man," Journal of Consumer Research, 29, 20-38. https://doi.org/10.1086/339919

Lewicka, Maria (2011a), "Place Attachment: How Far Have we Come in the Last 40 Years?," Journal of Environmental Psychology, 31 (3), 207-30. https://doi.org/10.1016/j.jenvp.2010.10.001

(2011b), "On the Varieties of People's Relationships with Places: Hummon's Typology Revisited," Environment and Behavior, 43 (5), 676-709. https://doi.org/10.1177/0013916510364917

Mayes, Robyn (2008), "A Place in the Sun: The Politics of Place, Identity and Branding," Place Branding and Public Diplomacy, 4 (2), 124-32. https://doi.org/10.1057/pb.2008.1

McCracken, Grant David (1988), "'Homeyness', A Cultural Account of one Constellation of Consumer Goods and Meanings," in Interpretive Consumer Research, E. C. Hirschman, ed. Provo, UT: Association for Consumer Research, 163-83.

Mernissi, Fatima (2010), Islam et Démocratie. Albin Michel.

Miles, Matthew B. and A. Michael Huberman (1984), Qualitative Data Analysis. Beverly Hills: Sage.

Newcomb, Rachel (2009), Women of Fes, Ambiguities of Urban Life in Morocco. Philadelphia: University of Pennsylvania Press.

Pollio, Howard R., Tracy B. Henley and Craig J. Thompson (1997), The Phenomenology of Everyday Life. Cambridge: Cambridge University Press. 
Pretty, Grace H., Heather M. Chipuer and Paul Bramston (2003), "Sense of Place amongst Adolescents and Adults in Two Rural Australian Towns: The Discriminating Features of Place Attachment, Sense of Community and Place Dependence in Relation to Place Identity," Journal of Environmental Psychology, 23, 273-87. https://doi.org/10.1016/S0272-4944(02)00079-8

Proshansky, Harold M., Abbe K. Fabian and Robert Kaminoff (1983), "Place Identity: Physical World Socialization of the Self," Journal of Environmental Psychology, 3 (1), 57-83. https://doi.org/10.1016/S0272-4944(83)80021-8

Sarkar, Sudipto (2019), "Parag Khanna, Connectography: Mapping the Future of Global Civilization (2016)," Markets, Globalization \& Development Review, 4 (4), Article 3. https://doi.org/10.23860/MGDR-2019-04-04-03

Scannell, Leila and Robert Gifford (2017), "The Experienced Psychological Benefits of Place Attachment," Journal of Environmental Psychology, 51, 256-69. https://doi.org/10.1016/i.jenvp.2017.04.001

Scherer, Klaus R. (2005), "What Are Emotions? And How Can they Be Measured?" Social Science Information, 44 (4), 695-729. https://doi.org/10.1177/0539018405058216

Sherry, John. F., Jr., Robert V. Kozinets, Diana Storm, Adam Duhachek, Krittinee Nuttavuthisit and Benet Deberry-Spence (2001), "Being in the Zone," Journal of Contemporary Ethnography, 30 (4): 465-10. https://doi.org/10.1177/089124101030004005

Skinner, Heather (2008), "The Emergence and Development of Place Branding's Confused Identity," Journal of Marketing Management, 24 (9-10), 915-28. https://doi.org/10.1362/026725708X381966

Stocchi, Lara, Cathy Hart and Iftakar Haji (2016), "Understanding the Town Center Customer Experience," Journal of Marketing Management, $32 \quad$ (17-18), 1562-87. https://doi.org/10.1080/0267257X.2016.1242510

Tanulku, Basak (2012), "Gated Communities: From "Self-Sufficient Towns" to "Active Urban Agents," Geoforum, 43 (3), 518-28. https://doi.org/10.1016/j.geoforum.2011.11.006 
Taylor, Ralph B. (1996), "Neighborhood Responses to Disorder and Local Attachments: The Systemic Model of Attachment, Social Disorganization, and Neighborhood Use Value," Sociological Forum, 11 (1), 41-74. https://doi.org/10.1007/BF02408301

Thompson, Craig J. (1997), "Interpreting Consumers: A Hermeneutical Framework for Deriving Marketing Insights from the Texts of Consumer's Consumption Stories," Journal of Marketing Research, 24, 438-55. https://doi.org/10.1177/002224379703400403

Thompson, Craig J., William B. Locander and Howard R. Pollio (1989), "Putting Consumer Experience back into Consumer Research: The Philosophy and Method of Existential Phenomenology," Journal of $\begin{array}{lllll}\text { Consumer } & \text { Research, } & 16 & \text { (9), } & \text { 133-46. }\end{array}$ https://doi.org/10.1086/209203

Thompson, Craig J., Howard R. Pollio and William B. Locander (1994), "The Spoken and the Unspoken: An Hermeneutic Approach to Understanding the Cultural Viewpoints that Underlie Consumers' Expressed Meanings," Journal of Consumer Research, 21 (3), $432-$ 52. https://doi.org/10.1086/209409

Twigger-Ross, Clare and David L. Uzzel (1996), "Place and Identity Processes," Journal of Environmental Psychology, 16, 205-20. https://doi.org/10.1006/jevp.1996.0017

Üstuner, Tuba and Douglas B. Holt (2007), "Dominated Consumer Acculturation: The Social Construction of Poor Migrant Women's Consumer Identity Projects in a Turkish Squatter," Journal of Consumer Research, 34 (1), 41-56. https://doi.org/10.1086/513045

Üstuner, Tuba and Douglas B. Holt (2010), "Toward a Theory of Status Consumption in Less Industrialized Countries," Journal of Consumer Research, 37 (1), 37-56. https://doi.org/10.1086/649759

Wester-Heber, Misse (2004), "Underlying Concerns in Land-Use ConflictsThe role of Place Identity in Risk Perception," Environmental Science \& Policy, 1, 109-16. https://doi.org/10.1016/j.envsci.2003.12.001 